\title{
Mature Embryo-Based in vitro Regeneration of Indica Rice Cultivars for High Frequency Plantlets Production
}

\author{
H N Barman ${ }^{1 *}$, M E Hoque², R K Roy², P L Biswas ${ }^{3}$, M A I Khan ${ }^{4}$, M O Islam 5
}

\begin{abstract}
The study was conducted at Biotechnology Division of Bangladesh Rice Research Institute (BRRI) to investigate the effects of plant growing medium and plant growth regulator (PGR) for the callus induction and high frequency plantlets regeneration of indica rice. Ten indica rice varieties viz. BR5, BR11, BRRI dhan28, BRRI dhan29, BRRI dhan33, BRRI dhan41, BRRI dhan47, BRRI dhan48, BRRI dhan49 and BRRI dhan50 were cultured on MS, N6 and LS media. The MS medium was found better for callus induction as compared to N6 and LS media. Among the tested varieties BRRI dhan48 induced the highest percent and best quality callus. Interaction effects of BRRI dhan 48 to MS medium yielded $71.55 \%$ callus induction. The regeneration efficiency of BRRI dhan48 was tested on MS medium supplemented with different combination of NAA plus BAP and NAA plus kinetin. MS medium supplemented with $2.0 \mathrm{mg} \mathrm{L}^{-1} \mathrm{NAA}$ and $2.0 \mathrm{mg} \mathrm{L}^{-1} \mathrm{Kn}$ was found the best in respect of percent regenerated $(76.67 \%)$ plantlet as well as for the growth of plantlets in vitro.
\end{abstract}

Key words: Indica rice (Oryza sativa L.), growing media, growth regulators, callus induction, regeneration

\section{INTRODUCTION}

Rice is the staple food of around $30-40 \%$ of the world population. Over $90 \%$ of rice is cultivated in Asia. Due to rapid climatic changes rice cultivation facing a threat of biotic (diseases and insects) and abiotic (saline, drought, submerse, cold, heat) stresses. Different research approaches like conventional breeding, somaclonal variation, marker assisted selection were carried out during last decades to develop tolerant rice varieties against above mentioned stresses. Though some remarkable progresses are achieved, that is not up to the mark. Genetic transformation is the important biotechnological tool for developing stresses tolerant rice varieties. However, the success of genetic transformation depends on several factors like genotypes, media, light, hormonal effect etc. Genetic transformation of rice with Agrobacterium requires suitable regeneration system from a transformed callus and ironically, shoot regeneration represents a major bottleneck in this endeavour. Most of the indica rice genotypes, the world's most cultivated rice types, still remain less amenable to genetic transformation due to their poor regeneration potential (Sahoo et al., 2011) Although reporting is abundant on callus induction, regeneration and also transformation in japonica rice, it is limited in indica rice. In this context, the evaluation of new factors and their manipulation for efficient callusing and green plant regeneration from mature embryo in indica rice is still challenging (Niroula et al., 2005). That is why, a detail study has long been demanding in callus induction and plantlets regeneration in indica rice. Therefore the present study was undertaken to select the best media for selected genotype.

\section{MATERIALS AND METHODS}

Plant materials, medium, layout and design The experiment was conducted at Biotechnology

${ }^{1}$ Plant Physiology Division, ${ }^{2}$ Biotechnology Division, ${ }^{3}$ Plant Breeding Division, ${ }^{4}$ Plant Pathology Division, Bangladesh Rice Research Institute (BRRI), Gazipur 1701, Bangladesh; ${ }^{5}$ Department of Crop Botany, Bangladesh Agricultural University (BAU), Mymensingh 2202, Bangladesh. *Corresponding author`s E-mail: hnbarman@yahoo.com 
Division of BRRI, Gazipur, Bangladesh. Ten BRRI released indica rice varieties viz BR5, BR11, BRRI dhan28, BRRI dhan29, BRRI dhan33, BRRI dhan41, BRRI dhan47, BRRI dhan48, BRRI dhan49 and BRRI dhan50 were used. Three culture media viz MS (Murashige and Skoog, 1962), N6 (Chu et al., 1975) and LS (Linsmaier and Skoog, 1965) were evaluated to select the best medium for callus induction and regeneration. The experiment was conducted in $18 \mathrm{~mm} \times 1.2 \mathrm{~mm}$ test tubes and laid out following a completely randomized design (CRD) with five replications.

\section{Callus induction}

To induce callus, dehusked mature embryo were cultured on MS, N6 and LS media and incubated in growth room at $25 \pm 2^{\circ} \mathrm{C}$ under $12 \mathrm{hr}$. photoperiod of $50 \mu \mathrm{mol} \mathrm{m} \mathrm{m}^{-2} \mathrm{~s}^{-1}$ provided by florescent tubes. The basal media were supplemented with $30.0 \mathrm{~g} \quad \mathrm{~L}^{-1}$ sucrose, $0.3 \mathrm{~g} \mathrm{~L}^{-1}$ casamino acid and $2.0 \mathrm{mg} \mathrm{L}^{-1} 2$, 4-Dichlorophenoxyacetic acid (2, 4-D) and solidified with $7.0 \mathrm{~g} \mathrm{~L}^{-1}$ agar. The $\mathrm{pH}$ of the media was adjusted to 5.8 prior to autoclave at $121^{\circ} \mathrm{C}$ with $1.16 \mathrm{~kg} \mathrm{~cm}^{-2}$ pressure for 20 minutes.

\section{Plant regeneration}

Three weeks old embryogenic calli of BRRI dhan48 and MS medium supplemented with different combinations of Naphthaleneacetic acid (NAA) + 6-Benzylaminopurine (BAP) and NAA + Kinetin $(\mathrm{Kn})$ were used for plant regeneration. The $\mathrm{pH}$ of the regeneration media were adjusted to 5.8 .

\section{Data collection}

The data on callus induction and plantlet regeneration were collected on 21 and 50 days after culture. Callus induction, regeneration, number of plantlets callus ${ }^{-1}$, average plantlet height, number of root plantlet ${ }^{-1}$, average root length etc were also collected. Data were analyzed to compare mean values to express treatments effects. The means were calculated and analysis of variance of all the characters was performed by F-test. Significance of the difference between the pair of means was evaluated by Duncan's Multiple Range Test (Gomez and Gomez, 1984) at the 5\% level of significance using MSTAT-C computer programmed (Russel, 1986).

\section{RESULTS}

\section{Callus induction}

Callus initiation in varieties. The highest percentage of callus induction was $59.60 \%$ found in BRRI dhan 48 followed by $53.27 \%$ in BRRI dhan 28 and the lowest was $26.43 \%$ in BRRI dhan49 (Table 1). Thus BRRI dhan 48 showed comparatively better potential in callus induction compared to other varieties. At the beginning scutelum callus was compact almost in all the varieties but turned into friable after two weeks of culture. Calli of BRRI dhan 48 were bright yellowish, glassy and looks most healthy compared to other varieties. Colour of

Table 1. Mean callus induction percent of rice varieties tested

\begin{tabular}{lc}
\hline Name of the varieties & Callus induction (\%) \\
\hline BR5 & $42.18 \mathrm{c}$ \\
BR11 & $37.82 \mathrm{~cd}$ \\
BRRI dhan28 & $53.27 \mathrm{~b}$ \\
BRRI dhan29 & $28.22 \mathrm{gh}$ \\
BRRI dhan33 & $41.07 \mathrm{~cd}$ \\
BRRI dhan41 & $36.67 \mathrm{de}$ \\
BRRI dhan47 & $31.48 \mathrm{fg}$ \\
BRRI dhan48 & $59.60 \mathrm{a}$ \\
BRRI dhan49 & $26.43 \mathrm{~h}$ \\
BRRI dhan50 & $33.11 \mathrm{ef}$ \\
\hline
\end{tabular}

Same letter in the column did not differ significantly at the $5 \%$ level of probability.

Table 2. Effect of media on mean callus induction percent of rice varieties tested

\begin{tabular}{lc}
\hline Media & Callus induction $(\%)$ \\
\hline MS & $47.00 \mathrm{a}$ \\
N6 & $36.08 \mathrm{~b}$ \\
LS & $33.88 \mathrm{~b}$ \\
\hline
\end{tabular}

Same letter in the column did not differ significantly at the $5 \%$ level of probability. 

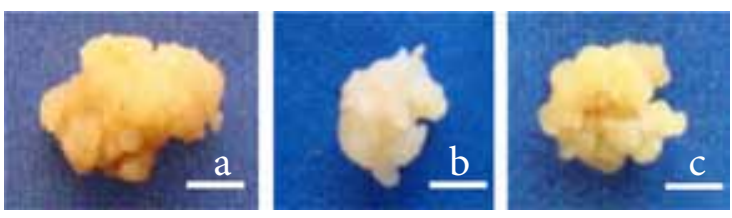

Fig. 1. Callus of a) BRRI dhan48 (yellowish), b) BRRI dhan28 (whitish) and c) BRRI dhan33 (light yellowish). Scale bar $=0.5 \mathrm{~cm}$.

the callus was whitish in BRRI dhan28 and light yellowish in BRRI dhan33 (Fig. 1a, 1b and 1c).

Effect of medium on callusing. Significant variation was observed in callus induction due to the effect of different culture media. The mean callus induction ranged from $33.88 \%$ to $47.00 \%$ (Table 2). The highest and the lowest callus induction were $47.00 \%$ and $33.88 \%$ found in MS medium and LS medium respectively.

Interaction effects of variety to medium on callus induction. The interaction effect of variety to medium on callus induction was varied significantly. The highest callus induction $71.55 \%$ was recorded in BRRI dhan 48 in MS medium followed by $63.47 \%$ in BRRI dhan28 in LS medium (Table 3). The lowest callus induction was $19.96 \%$ observed in BRRI dhan47 in N6 medium (Table 3).

\section{Plantlet regeneration}

Effects of NAA and BAP on plantlet regeneration. The plantlet regeneration from callus was found 2-3 weeks after transferred in the regeneration medium. All parameters showed significant variations depending on NAA and BAPsupplementintoMSmedium. The highest percent $(70.00 \%)$ regenerated plantlet was observed in medium supplemented with $2.0 \mathrm{mg} \mathrm{L}^{-1} \mathrm{NAA}$ and $1.0 \mathrm{mg} \mathrm{L}^{-1}$ BAP followed by $63.33 \%$ at NAA $2.0 \mathrm{mg} \mathrm{L}^{-1}$ and BAP $2.0 \mathrm{mg}$ $\mathrm{L}^{-1}$. The lowest percent $(16.67 \%)$ regenerated plantlet was in medium supplemented with 0.1 $\mathrm{mg} \mathrm{L}^{-1} \mathrm{NAA}$ and $0.5 \mathrm{mg} \mathrm{L}^{-1}$ BAP (Table 4). The highest number of plantlets was 12.3 per callus in medium supplemented with $2.0 \mathrm{mg} \mathrm{L}^{-1} \mathrm{NAA}$ and $1.0 \mathrm{mg} \mathrm{L}^{-1}$ BAP followed by 9.17 plantlets at NAA $2.0 \mathrm{mg} \mathrm{L}^{-1}$ and BAP $2.0 \mathrm{mg} \mathrm{L}^{-1}$ (Table $4)$. The highest average plant height was 10.18 $\mathrm{cm}$ in medium supplemented with $2.0 \mathrm{mg} \mathrm{L}^{-1}$ of
NAA and $1.0 \mathrm{mg} \mathrm{L}^{-1}$ BAP followed by $6.00 \mathrm{~cm}$ at NAA $1.0 \mathrm{mg} \mathrm{L}^{-1}$ and BAP $1.0 \mathrm{mg} \mathrm{L}^{-1}$ (Table 4). The highest average root length $7.33 \mathrm{~mm}$ was found in medium supplemented with $2.0 \mathrm{mg} \mathrm{L}^{-1}$ NAA and $1.0 \mathrm{mg} \mathrm{L}^{-1}$ BAP followed by $4.50 \mathrm{~mm}$ at NAA $2.0 \mathrm{mg} \mathrm{L}^{-1}$ and BAP $2.0 \mathrm{mg} \mathrm{L}^{-1}$ (Table 4 ). The maximum number of root plantlet $^{-1}$ was

Table 3. Interaction effects of variety to medium on callus induction in rice.

\begin{tabular}{|c|c|}
\hline Variety $\times$ Medium & Callus induction (\%) \\
\hline $\mathrm{BR} 5 \times \mathrm{MS}$ & $53.44 \mathrm{~d}$ \\
\hline BR11× MS & $47.38 \mathrm{e}$ \\
\hline BRRI dhan $28 \times$ MS & $48.70 \mathrm{e}$ \\
\hline BRRI dhan29 × MS & $30.95 \mathrm{jk}$ \\
\hline BRRI dhan33 × MS & 49.26 de \\
\hline BRRI dhan $41 \times$ MS & $47.52 \mathrm{e}$ \\
\hline BRRI dhan $47 \times$ MS & $38.21 \mathrm{fgh}$ \\
\hline BRRI dhan48 × MS & $71.55 \mathrm{a}$ \\
\hline BRRI dhan49 × MS & $31.20 \mathrm{jk}$ \\
\hline BRRI dhan50 × MS & $51.73 \mathrm{de}$ \\
\hline $\mathrm{BR} 5 \times \mathrm{N} 6$ & $31.43 \mathrm{jk}$ \\
\hline $\mathrm{BR} 11 \times \mathrm{N} 6$ & 34.08 hij \\
\hline BRRI dhan28 × N6 & $47.64 \mathrm{e}$ \\
\hline BRRI dhan29 × N6 & $29.58 \mathrm{jkl}$ \\
\hline BRRI dhan33 × MS & 49.52 de \\
\hline BRRI dhan41 × N6 & $39.60 \mathrm{fg}$ \\
\hline BRRI dhan47 × N6 & 19.96 o \\
\hline BRRI dhan48 × N6 & $58.68 \mathrm{c}$ \\
\hline BRRI dhan49 × N6 & 22.66 no \\
\hline BRRI dhan50 × N6 & $27.59 \mathrm{klm}$ \\
\hline $\mathrm{BR} 5 \times \mathrm{LS}$ & $41.67 \mathrm{f}$ \\
\hline $\mathrm{BR} 11 \times \mathrm{LS}$ & $32.00 \mathrm{ijk}$ \\
\hline BRRI dhan $28 \times$ LS & $63.47 \mathrm{~b}$ \\
\hline BRRI dhan29 × LS & $24.11 \mathrm{mno}$ \\
\hline BRRI dhan33 × LS & $24.42 \mathrm{mno}$ \\
\hline BRRI dhan $41 \times$ LS & 22.89 no \\
\hline BRRI dhan $47 \times$ LS & 36.25 ghi \\
\hline BRRI dhan $48 \times$ LS & $48.57 \mathrm{e}$ \\
\hline BRRI dhan49 × LS & $25.42 \mathrm{lmn}$ \\
\hline BRRI dhan50 × LS & $20.00 \mathrm{o}$ \\
\hline
\end{tabular}

Same letter in the column did not differ significantly at the $5 \%$ level of probability.

In vitro Regeneration of Indica Rice Cultivars 83 
Table 4. Effects of NAA combined to BAP on callus-derived plantlet regeneration.

\begin{tabular}{|c|c|c|c|c|c|c|}
\hline \multicolumn{2}{|c|}{ MS medium with } & \multirow{3}{*}{$\begin{array}{l}\text { Percent } \\
\text { regenerated } \\
\text { plantlet }\end{array}$} & \multirow{3}{*}{$\begin{array}{l}\text { Number of } \\
\text { plantlets }_{\text {callus }^{-1}}\end{array}$} & \multirow{3}{*}{$\begin{array}{l}\text { Average } \\
\text { plantlet } \\
\text { height } \\
(\mathrm{cm})\end{array}$} & \multirow{3}{*}{$\begin{array}{c}\text { Average } \\
\text { root } \\
\text { length } \\
(\mathrm{mm})\end{array}$} & \multirow{3}{*}{$\begin{array}{c}\text { Number of } \\
\text { root } \\
\text { plantlet }\end{array}$} \\
\hline NAA & BAP & & & & & \\
\hline $\mathrm{mg} \mathrm{L}^{-1}$ & $\mathrm{mg} \mathrm{L}^{-1}$ & & & & & \\
\hline 0.1 & 0.5 & 16.671 & $3.17 \mathrm{i}$ & 3.00 ef & $2.83 \mathrm{cdef}$ & $2.92 \mathrm{fgh}$ \\
\hline 0.1 & 1.0 & $20.00 \mathrm{kl}$ & 4.50 ghi & $2.83 \mathrm{efg}$ & $2.67 \mathrm{def}$ & 3.71 cdef \\
\hline 0.1 & 2.0 & $26.67 \mathrm{ijk}$ & 7.02 cde & $3.67 \mathrm{cde}$ & $3.83 \mathrm{bc}$ & 4.06 cde \\
\hline 0.1 & 4.0 & $23.33 \mathrm{jkl}$ & 4.50 ghi & $2.83 \mathrm{efg}$ & $3.83 \mathrm{bc}$ & $3.63 \mathrm{cdef}$ \\
\hline 0.25 & 0.5 & $26.67 \mathrm{ijk}$ & $4.17 \mathrm{hi}$ & 3.33 def & $3.83 \mathrm{bc}$ & 3.26 efg \\
\hline 0.25 & 1.0 & 30.00 hij & 6.83 def & $5.50 \mathrm{~b}$ & 3.33 cde & 3.99 cde \\
\hline 0.25 & 2.0 & 33.33 ghi & $7.83 \mathrm{bcd}$ & $4.00 \mathrm{~cd}$ & $3.50 \mathrm{bcd}$ & 3.97 cde \\
\hline 0.25 & 4.0 & $23.33 \mathrm{jkl}$ & $6.83 \mathrm{def}$ & 3.40 def & $3.50 \mathrm{bcd}$ & $4.87 \mathrm{~b}$ \\
\hline 0.5 & 0.5 & 33.33 ghi & $3.50 \mathrm{i}$ & $3.50 \mathrm{def}$ & $2.83 \mathrm{cdef}$ & 3.41 defg \\
\hline 0.5 & 1.0 & $40.00 \mathrm{fg}$ & $8.17 \mathrm{bcd}$ & $4.17 \mathrm{~cd}$ & 3.17 cdef & $4.34 \mathrm{bc}$ \\
\hline 0.5 & 2.0 & $36.67 \mathrm{gh}$ & $8.50 \mathrm{bc}$ & $4.33 c$ & $2.67 \mathrm{def}$ & $2.95 \mathrm{fgh}$ \\
\hline 0.5 & 4.0 & 30.00 hij & 4.67 ghi & $2.17 \mathrm{~g}$ & $2.33 \mathrm{ef}$ & $3.00 \mathrm{fgh}$ \\
\hline 1.0 & 0.5 & 46.67 ef & $8.83 \mathrm{~b}$ & $5.50 \mathrm{~b}$ & $2.83 \mathrm{cdef}$ & $4.38 \mathrm{bc}$ \\
\hline 1.0 & 1.0 & $56.67 \mathrm{bcd}$ & $8.50 \mathrm{bc}$ & $6.00 \mathrm{ab}$ & $2.50 \mathrm{def}$ & 4.05 cde \\
\hline 1.0 & 2.0 & $60.00 \mathrm{bc}$ & $8.50 \mathrm{bc}$ & $5.50 \mathrm{~b}$ & 2.50 def & $4.18 \mathrm{bcd}$ \\
\hline 1.0 & 4.0 & 50.00 de & $5.50 \mathrm{fgh}$ & 3.50 def & $2.17 \mathrm{f}$ & $2.79 \mathrm{gh}$ \\
\hline 2.0 & 0.5 & $56.67 \mathrm{bcd}$ & $5.83 \mathrm{efg}$ & $2.77 \mathrm{fg}$ & $2.16 \mathrm{f}$ & $2.25 \mathrm{~h}$ \\
\hline 2.0 & 1.0 & $70.00 \mathrm{a}$ & $12.33 \mathrm{a}$ & $10.18 \mathrm{a}$ & $7.33 \mathrm{a}$ & $5.90 \mathrm{a}$ \\
\hline 2.0 & 2.0 & $63.33 \mathrm{ab}$ & $9.17 \mathrm{~b}$ & $3.33 \mathrm{def}$ & $4.50 \mathrm{~b}$ & 4.00 cde \\
\hline 2.0 & 4.0 & 53.33 cde & 7.17 cde & $3.50 \mathrm{cdef}$ & $2.17 \mathrm{f}$ & $3.45 \mathrm{defg}$ \\
\hline
\end{tabular}

Same letter in the column did not differ significantly at the $5 \%$ level of probability.

5.90, found in medium supplemented with 2.0 $\mathrm{mg} \mathrm{L^{-1 }}$ NAA and $1.0 \mathrm{mg} \mathrm{L}^{-1}$ BAP followed by 4.87 roots at NAA $0.25 \mathrm{mg} \mathrm{L}^{-1}$ and BAP $4.0 \mathrm{mg}$ $\mathrm{L}^{-1}$. The lowest number of root plantlet ${ }^{-1}$ was 2.25 found in medium supplemented with $2.0 \mathrm{mg} \mathrm{L}^{-1} \mathrm{NAA}$ and $0.5 \mathrm{mg} \mathrm{L}^{-1}$ BAP (Table 4). The results revealed that data on percent regenerated plantlet, number of plantlets callus $^{-1}$, average plantlet height, average root length and number of root plantlet ${ }^{-1}$ were best in MS medium supplemented with $2.0 \mathrm{mg} \mathrm{L}^{-1}$ NAA and $1.0 \mathrm{mg} \mathrm{L}^{-1}$ BAP. Figures $2 \mathrm{a}, 2 \mathrm{~b}$ and $2 \mathrm{c}$ show the regenerated plantlet in MS medium with different concentration of NAA and BAP.

Effects of NAA and Kinetin on plantlet regeneration. All parameters (Table 5) showed significant variations due to application of different levels of NAA and Kn in MS medium. The highest percent $(76.67 \%)$ regenerated plantlet was found in medium supplemented with $2.0 \mathrm{mg} \mathrm{L}^{-1} \mathrm{NAA}$ and $2.0 \mathrm{mg}$ $\mathrm{L}^{-1} \mathrm{Kn}$ followed by $66.67 \%$ at $1.0 \mathrm{mg} \mathrm{L}^{-1} \mathrm{NAA}$ and $2.0 \mathrm{mg} \mathrm{L}^{-1} \mathrm{Kn}$. The lowest plantlet $(26.67 \%)$ regenerated in medium supplemented with $0.1 \mathrm{mg} \mathrm{L}^{-1} \mathrm{NAA}$ and $0.5 \mathrm{mg} \mathrm{L}^{-1} \mathrm{Kn}$ (Table 5). The highest number of plantlets (12.17) was obtained in medium supplemented with 2.0 mg L-1 NAA and $2.0 \mathrm{mg} \mathrm{L}^{-1} \mathrm{Kn}$ followed by plantlets (10.0) at $1.0 \mathrm{mg} \mathrm{L}^{-1} \mathrm{NAA}$ and $2.0 \mathrm{mg}$ $\mathrm{L}^{-1} \mathrm{Kn}$. The medium supplemented with 0.25 $\mathrm{mg} \mathrm{L}^{-1} \mathrm{NAA}$ and $0.5 \mathrm{mg} \mathrm{L}^{-1} \mathrm{Kn}$ produced the lowest number of plantlets (2.0) (Table 5). The highest average plant height was $9.17 \mathrm{~cm}$ in medium supplemented with $2.0 \mathrm{mg} \mathrm{L}^{-1} \mathrm{NAA}$ 

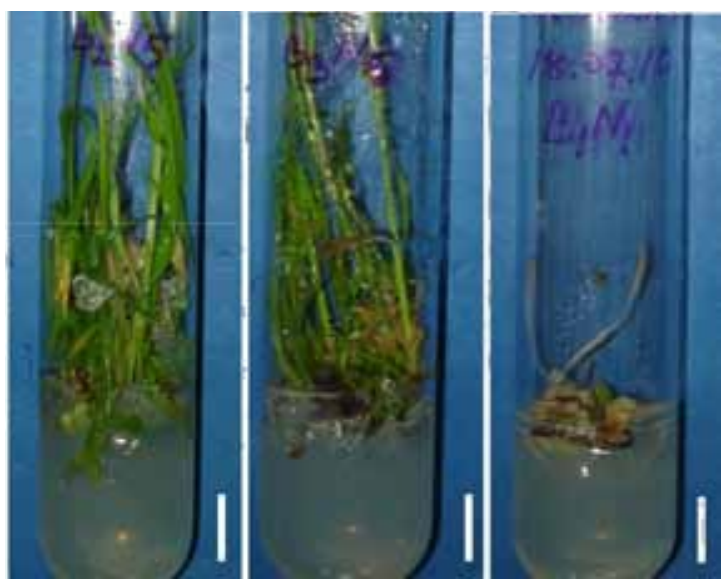

a) $2.0 \mathrm{mg} \mathrm{L}^{-1} \mathrm{NAA} \quad$ b) $2.0 \mathrm{mg} \mathrm{L}^{-1} \mathrm{NAA} \quad$ c) $0.1 \mathrm{mg} \mathrm{L}^{-1} \mathrm{NAA}$

$+1.0 \mathrm{mg} \mathrm{L}^{-1} \mathrm{BAP}+2.0 \mathrm{mg} \mathrm{L}^{-1} \mathrm{BAP}+0.5 \mathrm{mg} \mathrm{L}^{-1} \mathrm{BAP}$

Fig. 2. Regenerated plantlet in MS medium with different concentration of NAA and BAP. Scale bar $=1.0 \mathrm{~cm}$. and $2.0 \mathrm{mg} \mathrm{L}^{-1} \mathrm{Kn}$ followed by $7.67 \mathrm{~cm}$ at 1.0 $\mathrm{mg} \mathrm{L}^{-1} \mathrm{NAA}$ and $2.0 \mathrm{mg} \mathrm{L}^{-1} \mathrm{Kn}$ (Table 5). The highest average root length was $9.17 \mathrm{~mm}$ in medium supplemented with $2.0 \mathrm{mg} \mathrm{L}^{-1} \mathrm{NAA}$ and $2.0 \mathrm{mg} \mathrm{L}^{-1} \mathrm{Kn}$ followed by $7.17 \mathrm{~mm}$ at 1.0 $\mathrm{mg} \mathrm{L}^{-1} \mathrm{NAA}$ and $2.0 \mathrm{mg} \mathrm{L}^{-1} \mathrm{Kn}$ and the lowest was $2.17 \mathrm{~mm}$ in medium supplemented with $1.0 \mathrm{mg} \mathrm{L}^{-1} \mathrm{NAA}$ and $0.5 \mathrm{mg} \mathrm{L}^{-1} \mathrm{Kn}$ (Table 5). The maximum number (10.69) of roots were developed in medium supplemented with $2.0 \mathrm{mg} \mathrm{L}^{-1} \mathrm{NAA}$ and $2.0 \mathrm{mg} \mathrm{L}^{-1} \mathrm{Kn}$ and the lowest was 1.85 in medium supplemented with $0.5 \mathrm{mg} \mathrm{L}^{-1} \mathrm{NAA}$ and $0.5 \mathrm{mg} \mathrm{L}^{-1} \mathrm{Kn}$ (Table 5). The results revealed that data on percent regenerated plantlet, number of plantlets callus $^{-1}$, average plantlet height, average root length and number of root plantlet ${ }^{-1}$ were the best in MS medium supplemented with 2.0

Table 5. Effects of NAA combined to Kn on callus-derived plantlet regeneration.

\begin{tabular}{|c|c|c|c|c|c|c|}
\hline \multicolumn{2}{|c|}{ MS medium with } & \multirow{2}{*}{$\begin{array}{l}\text { Percent } \\
\text { regenerated } \\
\text { plantlet }\end{array}$} & \multirow{2}{*}{$\begin{array}{l}\text { Number of } \\
\text { plantlets } \\
\text { callus }^{-1}\end{array}$} & \multirow{2}{*}{$\begin{array}{c}\text { Average } \\
\text { plantlet } \\
\text { height } \\
(\mathrm{cm})\end{array}$} & \multirow{2}{*}{$\begin{array}{c}\text { Average } \\
\text { root } \\
\text { length }(\mathrm{mm})\end{array}$} & \multirow{2}{*}{$\begin{array}{c}\text { Number } \\
\text { of root } \\
\text { plantlet }^{-1}\end{array}$} \\
\hline NAA mg L ${ }^{-1}$ & $\mathrm{Kn} m g \mathrm{~L}^{-1}$ & & & & & \\
\hline 0.1 & 0.5 & $26.67 \mathrm{i}$ & $5.00 \mathrm{fg}$ & 4.50 efg & $3.17 \mathrm{fgh}$ & 4.33 efgh \\
\hline 0.1 & 1.0 & $36.67 \mathrm{gh}$ & $6.50 \mathrm{de}$ & $6.17 \mathrm{~cd}$ & $5.50 \mathrm{~cd}$ & $5.27 \mathrm{de}$ \\
\hline 0.1 & 2.0 & $66.67 \mathrm{~b}$ & $7.67 \mathrm{c}$ & $7.17 \mathrm{bc}$ & $6.00 \mathrm{c}$ & $5.79 \mathrm{~d}$ \\
\hline 0.1 & 4.0 & $56.67 \mathrm{~cd}$ & $5.50 \mathrm{ef}$ & 5.50 de & $4.50 \mathrm{de}$ & $5.38 \mathrm{de}$ \\
\hline 0.25 & 0.5 & $43.33 \mathrm{fg}$ & $2.00 \mathrm{~h}$ & $4.00 \mathrm{fgh}$ & 4.00 efg & $7.11 \mathrm{bc}$ \\
\hline 0.25 & 1.0 & $56.67 \mathrm{~cd}$ & $4.00 \mathrm{~g}$ & $3.17 \mathrm{hi}$ & $4.17 \mathrm{ef}$ & $4.09 \mathrm{fgh}$ \\
\hline 0.25 & 2.0 & $63.33 \mathrm{bc}$ & $6.17 \mathrm{de}$ & $5.17 \mathrm{de}$ & $4.50 \mathrm{de}$ & 3.33 hij \\
\hline 0.25 & 4.0 & 46.67 ef & $2.83 \mathrm{~h}$ & $3.17 \mathrm{hi}$ & $4.33 \mathrm{e}$ & $4.08 \mathrm{ghi}$ \\
\hline 0.5 & 0.5 & $33.33 \mathrm{hi}$ & $6.50 \mathrm{de}$ & $3.83 \mathrm{fgh}$ & $3.00 \mathrm{gh}$ & $1.85 \mathrm{k}$ \\
\hline 0.5 & 1.0 & $36.67 \mathrm{gh}$ & $6.50 \mathrm{de}$ & $2.67 \mathrm{i}$ & $3.17 \mathrm{fgh}$ & $2.65 \mathrm{jk}$ \\
\hline 0.5 & 2.0 & $40.00 \mathrm{fgh}$ & $4.500 \mathrm{fg}$ & $3.17 \mathrm{hi}$ & $3.17 \mathrm{fgh}$ & $3.16 \mathrm{ij}$ \\
\hline 0.5 & 4.0 & $33.33 \mathrm{hi}$ & $7.33 \mathrm{~cd}$ & $7.17 \mathrm{bc}$ & $3.17 \mathrm{fgh}$ & $2.49 \mathrm{jk}$ \\
\hline 1.0 & 0.5 & 33.33 hi & $6.37 \mathrm{de}$ & $6.83 \mathrm{bc}$ & $2.17 \mathrm{~h}$ & $7.54 \mathrm{~b}$ \\
\hline 1.0 & 1.0 & $46.67 \mathrm{ef}$ & $7.33 \mathrm{~cd}$ & $7.00 \mathrm{bc}$ & $2.33 \mathrm{~h}$ & $7.35 \mathrm{bc}$ \\
\hline 1.0 & 2.0 & $66.67 \mathrm{~b}$ & $10.00 \mathrm{~b}$ & $7.67 \mathrm{~b}$ & $7.17 \mathrm{~b}$ & $5.84 \mathrm{~d}$ \\
\hline 1.0 & 4.0 & $56.67 \mathrm{~cd}$ & $4.30 \mathrm{~g}$ & 3.50 ghi & $4.50 \mathrm{de}$ & $5.40 \mathrm{de}$ \\
\hline 2.0 & 0.5 & $43.33 \mathrm{fg}$ & $7.33 \mathrm{~cd}$ & $6.17 \mathrm{~cd}$ & $4.33 \mathrm{e}$ & $5.24 \mathrm{def}$ \\
\hline 2.0 & 1.0 & $56.67 \mathrm{~cd}$ & $6.50 \mathrm{de}$ & $6.67 \mathrm{bc}$ & $5.50 \mathrm{~cd}$ & $6.24 \mathrm{~cd}$ \\
\hline 2.0 & 2.0 & $76.67 \mathrm{a}$ & $12.17 \mathrm{a}$ & $9.17 \mathrm{a}$ & $9.17 \mathrm{a}$ & $10.69 \mathrm{a}$ \\
\hline 2.0 & 4.0 & 53.33 de & $5.50 \mathrm{ef}$ & $4.83 \mathrm{ef}$ & $5.50 \mathrm{~cd}$ & 5.13 defg \\
\hline
\end{tabular}

Same letter in a column did not differ significantly at the $5 \%$ level of probability. 


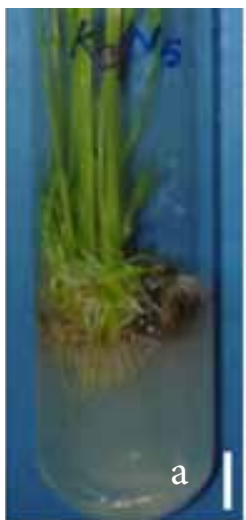

a) $2.0 \mathrm{mg} \mathrm{L}^{-1} \mathrm{NAA}$ $+2.0 \mathrm{mg} \mathrm{L}^{-1} \mathrm{Kn}$

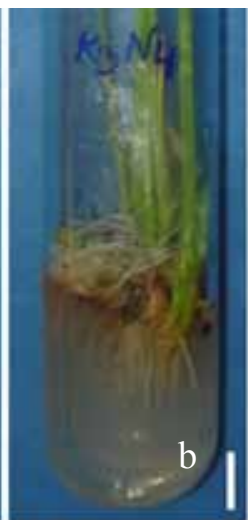

b) $1.0 \mathrm{mg} \mathrm{L}^{-1} \mathrm{NAA}$ $+2.0 \mathrm{mg} \mathrm{L}^{-1} \mathrm{Kn}$

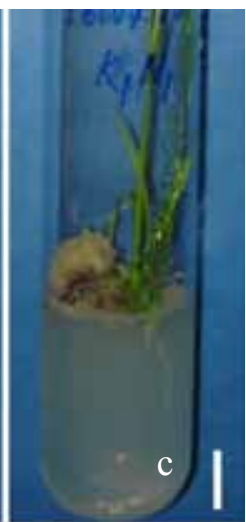

c) $0.1 \mathrm{mg} \mathrm{L}^{-1} \mathrm{NAA}$ $+0.5 \mathrm{mg} \mathrm{L}^{-1} \mathrm{Kn}$

Fig. 3. Regenerated plantlet in MS medium with different concentrations of NAA and $\mathrm{Kn}$. Scale bar $=1.0 \mathrm{~cm}$.

mg L-1 NAA and $2.0 \mathrm{mg} \mathrm{L}^{-1} \mathrm{Kn}$. Figures $3 \mathrm{a}, 3 \mathrm{~b}$ and $3 c$ show the regenerated plantlet in MS medium with different concentration of NAA and $\mathrm{Kn}$.

\section{DISCUSSION}

\section{Callus induction}

There are many factors influence callus induction in rice like genotype potentiality, $\mathrm{pH}$ of the media, plant growth regulators (PGRs) supplement, solidification of culture medium, light intensity, etc. Ge et al., 2006; Khaleda and Al-Forkan (2006) reported that mature dehusked rice seeds were good for callus induction because of callus initiated from scutellum of mature rice seeds have high embryogenic potentiality. Other researchers (Rashid et al., 2003; Cho et al., 2004; Ge et al., 2006) also reported that embryogenic calli were the excellent material for transformation of rice by using Agrobacterium. Khalequzzaman et al. (2005) also reported embryogenic calli obtained from mature rice seeds have high regeneration capacity. MS, LS and N6 are the most commonly used basal media for calli induction and regeneration (Pandey et al., 1994). BRRI dhan 48 in MS medium gave better callus induction as compared to LS and N6

media respectively. This findings were similar to the report by Khana and Raina (1998) who indicated that genotype was one of the major determinants in embryogenic callus induction. Al-Forkan et al. (2005), Gul et al. (2000) and Lee et al. (2000) also reported that embryogenic callus formation and plantlet regeneration were influenced by culture medium and genotype. The concentrations of plant growth regulator also affect the callusing of the genotypes. In this study, 2,4-D was used at the rate of $2 \mathrm{mg} \mathrm{L}^{-1}$. Previous studies also showed that callus could be induced better in $2 \mathrm{mg} \mathrm{L}^{-1}$ 2,4-D (Mosavi et al., 2001; Sikder et al., 2006). These results are confirmatory to the finding of other researchers (Niroula et al., 2005; Islam et al., 2004; Azria and Bhalla, 2000). Thus present investigation revealed that both genotype and media composition and their interaction largely affect on callus induction.

\section{Regeneration}

In-vitro plant regeneration was investigated on MS medium supplemented with different combinations of NAA + BAP and NAA + kinetin. A number of factors, such as genotype, developmental stage of cells in the explants, PGR composition in the medium, carbohydrates source, have been reported to improve the frequency of plantlet regeneration in rice. After transferring the calli into regeneration medium, green spots became visible on the surface of the calli within 5-7 days and after 30-35 days fully rooted shoots were developed. MS medium supplemented with $2.0 \mathrm{mg} \mathrm{L}^{-1} \mathrm{NAA}$ and 2.0 $\mathrm{mg} \mathrm{L}^{-1} \mathrm{Kn}$ was found the best in respect to percent regenerated plantlet $(76.67 \%)$ as well as for the growth of plantlets in vitro. The addition of small amount of $\mathrm{Kn}$ has been reported to improve embryogenic calli and shoot formation efficiency (Nhut et al., 2000; Afrasiab and Jafar, 2011) in indica rice. Present finding agree with the result of Lee et al. (2002) where it was reported that $\mathrm{Kn}$ was found to be more effective for plantlets regeneration compared with 
BAP. Combinations of auxin and cytokinin along with the effect of basal salts played an important role for plant regeneration (Prodhan et al., 2001; Lee et al., 2002).

\section{CONCLUSIONS}

In present study MS medium gave better callus induction as compared to LS and N6 media respectively. Percent regenerated plantlet was found highest in BRRI dhan 48 when cultured in MS medium supplemented with NAA and $\mathrm{Kn}$ compared to MS medium supplemented with NAA and BAP. Thus this finding revealed that $\mathrm{Kn}$ was more effective than BAP for regeneration and organogenesis. The present result might be helpful in future research on genetic transformation as well as in selection of stress tolerant cultivar development programme. From the result it might be concluded that MS medium for callus induction and MS medium supplemented with $2.0 \mathrm{mg} \mathrm{L}^{-1} \mathrm{NAA}$ and 2.0

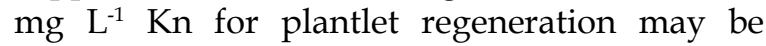
recommended for future research work.

\section{REFERENCES}

Afrasiab, $\mathrm{H}$ and $\mathrm{R}$ Jafar. 2011. Effect of different media and solidifying agents on callogenesis and plant regeneration from different explants of rice (Oryza sativa L.) varieties Super Basmati and IRRI-6. Pak. J. Bot. 43: 487-501.

Al-Forkan, M, M A Rahim, T Chowdhury, P Akter and L Khaleda. 2005. Development of highly in vitro callogenesis and regeneration system for some salt tolerant rice (Oryza sativa L.) cultivars of Bangladesh. J. Biotech. 4(3): 230-234.

Azria, D and P L Bhalla. 2000. Plant regeneration from mature embryo-derived callus of Australian rice (Oryza sativa L.) varieties. Aus. J. Agric. Res. 51(2): 305-312.

Cho, J H, J Y Lee and W Y Kim. 2004. Improvement of shoot regeneration from scutellum derived callus in rice. Korean J. Crop Sci. 49(1): 52-60.

Chu, C C, C C Wang, C S Sun, C Hus, K C Yin and C Y Chu. 1975. Establishment of an efficient medium for anther culture of rice through comparative experiments on the nitrogen sources. Scientia Sinica, 18: 659-668.

Ge, X J, H Z Chu, Y J Lin and S P Wang. 2006. A tissue culture system for different germplasms of Indica rice. Plant Cell Reports, 25(5): 392-402.
Gomez, K A and A A Gomez. 1984. Statistical procedures for agricultural research. John Willey and Sons, New York, pp. 207-215.

Islam, M M, S A Wahed and K U Khan. 2004. Studies on callus induction and regeneration from dehusked rice (Oryza sativa L.) Seeds. Plant Tissue Culture, 14(2): 155-160.

Khalequzzaman, M, N Haq, M E Hoque and T L Aditya. 2005. Regeneration efficiency and genotypic effect of 15 Indica type Bangladeshi rice (Oryza sativa L.) Landraces. Plant Tissue Culture, 15(1): 33-42.

Khanna, H K and S K Raina. 1998. Genotype $\times$ culture media interaction effects on regeneration response of three Indica rice cultivers. Plant Cell, Tissue and Organ Culture, 52: 145-153.

Lee, K S, S H Jeon and Y M Kim. 2002. Optimization of mature embryo based in vitro culture system for high frequency embryogenesis callus induction and plant regeneration from Japonica rice cultivars. Plant Cell, Tissue and Organ Culture, 71: 9-13.

Linsmaier, E M and F Skoog. 1965. Organic growth factor requirements of tobacco tissue culture. Plant Physiol, 21: 487-492.

Mosavi, A K, M Ghorbani and H Ebrahimzadeh. 2001. Somatic embryogenesis and regeneration of mature and immature embryos of six cultivars of rice (Oryza sativa L.). J. Agric. Sci. 7(1): 55-78.

Murashige, T and F Skoog. 1962. Revised medium for rapid growth and bioassay with tobacco tissue culture. Physiologia Plantarum, 15: 472-493.

Nhut, D T, B V Le and T T Van. 2000. Somatic embryogenesis and direct shoot regeneration of rice (Oryza sativa L.) using thin cell layer culture of apical meristematic tissue. J. Pl. Physiol. 157: 559-565.

Niroula, R K, B P Sah, H P Bimb and S Nayak. 2005. Effect of genotype and culture media on callus induction and plant regeneration from matured rice grain culture. $J$. Inst. Agric. Animal Sci. 26: 21-26.

Pandey, S K, B Ramesh and P K S Gupta. 1994. Callusing and plant regeneration in rice. Indian J. Genet. 54(3): 293- 299.

Prodhan, S H, K Nagamiya, A Komamine and Y Hirai. 2001. Regneration response of Indica and Japonica rice in different media. Bangladesh J. Pl. Breed. Genet. 14(2): 1-6.

Rashid,H,FM Abbasi and A Quraishi. 2003. Plant regeneration from seed derived callus of three varieties of Basmati rice. Plant Tissue Culture, 13(1): 75-79.

Revathy, N, M Muthusamy, K Seetheraman, I Yesuraja and E Rajeswari. 2000. Standardisa tion of media and growth hormone for callus induction from two rice genotypes. J. Eco-Physiol. 3: 83-86.

Russel, D F. 1986. MSTAT-C, MSTAT Director, Crop and Soil Science Department, Michigan State University, USA.

Sikder, M B H, P K Sen, M A Mamun, M R Ali and S M Rahman. 2006. in vitro regeneration of aromatic rice (Oryza sativa L.). Int. J. Agric. Biol. 8(6): 759-762.

Sahoo K K, A K Tripathi, A Pareek, S K Sopory and S L Singla-Pareek. 2011. An improved protocol for efficient transformation and regeneration of diverse indica rice cultivars. Plant Methods. 7: 49.

In vitro Regeneration of Indica Rice Cultivars 87 
